Maurer School of Law: Indiana University

Digital Repository @ Maurer Law

$12-2018$

\title{
Legal Principles and Seminal Legal Cases in Oocyte Donation
}

Jody L. Madeira

Susan L. Crockin

Follow this and additional works at: https://www.repository.law.indiana.edu/facpub

Part of the Health Law and Policy Commons, Medical Jurisprudence Commons, Obstetrics and Gynecology Commons, and the Women's Health Commons 


\title{
Legal principles and seminal legal cases in oocyte donation
}

\author{
Jody Lyneé Madeira, J.D., Ph.D. ${ }^{a}$ and Susan L. Crockin, J.D. ${ }^{b}$ \\ ${ }^{a}$ Maurer School of Law, Indiana University, Bloomington, Indiana; and ${ }^{\text {b }}$ Georgetown Law Center, Kennedy Institute of \\ Ethics, Georgetown University, Washington, DC
}

Oocyte donation has played an increasingly important role in assisted reproductive technologies since the early 1980s. Over the past 30 years, unique legal standards have evolved to address issues in the oocyte donation procedure itself as well as the disputes over issues, such as parentage, that inevitably arise with new technologies, particularly for individuals seeking to build nontraditional families. This essay will explore oocyte donation's legal aspects as well as seminal law concerning the procedure, including statutory law (uniform and model provisions and enacted state laws) and selected judicial opinions concerning surrogacy and parentage, testing of oocyte donors, mix-ups of donated oocytes, and donor compensation. (Fertil Steril ${ }^{\circledR}$ 2018;110:1209-15. (C2018 by American Society for Reproductive Medicine.)

Key Words: Oocyte donation, ova, ovum, law, assisted reproductive technology

Discuss: You can discuss this article with its authors and other readers at https://www.fertstertdialog.com/users/16110-fertilityand-sterility/posts/37783-26658

I $\mathrm{n}$ vitro fertilization (IVF) using donor oocytes is undoubtedly an important assisted reproductive technology (ART) procedure in the United States; in 2015, donor eggs were used in 19,482 ART cycles $(7,331$ fresh and 12,151 frozen); 4\% of women under the age of 35 years used donor eggs, compared with 34\% of women aged 43-44 and 71\% of women over 44 years (1). The percentage of oocyte-donor embryo transfers resulting in live births is consistently above $5 \%$ (1). Today, oocyte donation is particularly useful for women who lack functioning ovaries, are of advanced reproductive age, or risk passing genetic conditions to offspring (2), as well as for men, single individuals, and same-sex couples who lack ready access to oocytes or experience poor oocyte quality or ovarian reserve.

Oocyte donation is a fairly recent development; during the first U.S. procedure in 1983 at the Harbor UCLA Medical Center, Dr. John Buster removed an embryo from a donor's uterus with the use of lavage and transferred it to an intended mother's uterus (3), leading to the first live birth from a donor oocyte in 1984 (2). Initially, donated oocytes came from an intended mother's close friends and relatives ("known donation") or from other women undergoing IVF willing to donate surplus oocytes-a practice that rapidly declined with the advent of embryo cryopreservation (4). In the late 1980s, great demand and dwindling supply motivated fertility clinics to begin recruiting donors from the general population; initially, donors were unpaid, but clinics began to advertise for paid donors around 1990 (typically offering \$2,000-\$2,500) (4). In 1991, one of the first commercial oocyte donation programs opened in California (4).

In general, sperm donation laws have paved the way for both social acceptance of oocyte donation and legal protections for intended parents

Received July 16, 2018; revised August 8, 2018; accepted August 13, 2018.

J.L.M. has nothing to disclose. S.L.C. has nothing to disclose.

Reprint requests: Jody Lyneé Madeira, J.D., Ph.D., 211 S. Indiana Avenue, Bloomington, IN 47405 (E-mail: jmadeira@indiana.edu).

(4). But obvious differences between sperm and oocyte donation and different real-world consequences necessitated that these procedures be regulated by different legal standards. This essay considers legal aspects and seminal case law concerning oocyte donation. We first discuss professional American Society for Reproductive Medicine (ASRM) guidelines regarding oocyte donation that have both informed and drawn on legal statutes and judicial opinions, after which we discuss relevant statutory law, including uniform and model provisions and enacted state laws. Finally, we discuss a number of judicial opinions concerning surrogacy and parentage, testing of oocyte donors, mix-ups of donated oocytes, and oocyte donor compensation.

\section{ASRM GUIDELINES REGARDING OOCYTE DONATION}

ASRM has issued ethics and practice committee opinions concerning several topics related to oocyte donation, including use of family members, financial compensation, disclosure of medical errors, oocyte donation to women of advanced reproductive age, 
posthumous retrieval and use, informed consent (including for donation for research purposes), informing offspring of their conception, third-party ART misconduct, and interests, obligations, and rights in gamete donation. Adherence to both practice and ethics guidelines is a requirement of ASRM membership (5). Although these standards lack the force of law, they provide essential evidence for establishing the medical standard of care in civil medical malpractice suits.

ASRM Practice Committee guidelines urge physicians to "strongly recommend counseling by a qualified mental health professional to all intended parents using donor gametes" (6), as well as psychosocial evaluation and counseling for potential gamete donors and their partners. In general, programs must inform donors and recipients about pertinent legal, medical, and emotional issues, medical screening, and information sharing, and counsel them that the donation relationship is life-long and subject to "evolving medical technology, laws, and social standards" (7). The ASRM Ethics Committee has noted that minimal obligations include authorizing "disclosure of nonidentifying medical information where appropriate" and recommended that these issues be discussed in the consent process, together with the possibility that legal and policy changes could make "promises of anonymity or future contact" unenforceable (7).

Moreover, ASRM Ethics Committee opinions suggest that programs limit the number of times a woman can undergo retrieval for donation purposes and make "good-faith efforts" to avoid frequent oocyte donors (8); ASRM Practice Committee standards recommend limiting donors to six stimulated cycles (9). Use of adult relatives as gamete donors or surrogates is generally acceptable if they are not consanguineous, do not involve child-to-parent donations, or simulate incestuous unions (e.g., ovum donation from sister to brother's wife); such arrangements, however, may require additional screening and counseling (10). ASRM ethical guidelines suggest that women of advanced reproductive age (over 45 years) considering donor oocytes undergo comprehensive medical and psychosocial evaluation and counseling, and they discourage providing donor oocytes to women over 55 year old (11). Programs can ethically decline to provide treatment based on "well grounded reasons that those patients will be unable to provide minimally adequate or safe care for offspring" (12).

According to ASRM Ethics Committee guidelines, financial compensation of oocyte donors is justified, and should be "structured to acknowledge the time, inconvenience, and discomfort associated with screening, ovarian stimulation, and oocyte retrieval" but not based on the oocytes' planned use, number or quality retrieved, number or outcome of previous donation cycles, or ethnic or personal characteristics (8). Financial compensation includes both payments to women donating oocytes for others' use, and reduced IVF costs for women undergoing IVF who provide some oocytes to another patient (8). Payments should not "become undue inducements that will lead donors to discount risks" (8). Physicians owe oocyte donors the same duties as other patients, and programs should adopt and disclose policies concerning payment of medical costs for donor complications (7).
Finally, ASRM Ethics Committee guidelines authorize physicians to disclose material information when a thirdparty reproduction participant refuses to do so (13). Programs should also have "rigorous procedures" to prevent "loss, degradation, or misdirection of gametes and embryos" and ensure proper identification; and clinics have an "ethical obligation to disclose errors," and must disclose errors in which "gametes or embryos are mistakenly switched" immediately upon discovery (14).

\section{STATUTORY LAW GOVERNING OOCYTE DONATION}

In addition to professional guidelines, a number of statutory laws govern oocyte donation and parentage thereafter. These statutory laws can be classified into two groups: 1) uniform laws or model acts; and 2) enacted state laws. The $1984 \mathrm{Na}-$ tional Organ Transplant Act (15) makes it illegal to buy and sell certain body parts or tissues for specific purposes but expressly excludes renewable tissue such as sperm and blood. Although eggs are not renewable, it has generally been accepted that compensating egg donors for their "time, effort, and inconvenience" is also not prohibited (16).

\section{Uniform Laws and Model Acts}

The Uniform Parentage Act (UPA), a set of rules for establishing parentage that state legislatures can adopt in part or in entirety, was first approved in 1973 by the Uniform Conference of Commissioners of Uniform State Laws, a nonprofit association formed in 1892 to ensure uniformity of state law in certain crucial areas (such as family law). The Uniform Conference is composed of more than 300 volunteer members of the bar (usually practitioners, judges, and law professors). No uniform law is effective until a state legislature adopts it. Uniform laws have been approved for several subjects; for example, the Uniform Probate Code (UPC) also addresses ART-related parentage and inheritance issues. The UPA (1973) was revised in 2002 and 2017.

The UPA (1973) legitimated children conceived from sperm donation, was widely adopted by the majority of states, and formed the cornerstone for most state donor insemination and parentage laws (17). It provided that sperm donors providing gametes to physicians were not legal parents but was silent regarding oocyte donors (likely because it was approved before oocyte donation was technologically feasible). Revisions in 2002 streamlined several provisions, incorporating a paternity registry and nonjudicial procedures for acknowledging paternity, genetic testing, authorizing surrogacy agreements, and surrogacy parentage determinations. Critically, following the U.S. Supreme Court's decisions in Obergefell $v$. Hodges (18) in 2015 (establishing the constitutionality of same-sex marriage) and Pavan v. Smith (19) in 2017 (upholding same-sex parents' right to be listed on children's birth certificates), the UPA 2017 revision amends several provisions to ensure equal treatment of same-sex couples' children and equal recognition of intended parents regardless of sex, sexual orientation, or marital status (17). Finally, for the first time, UPA (2017) article 9 addresses 
"rights of donor-conceived persons to access medical and identifying information"; it does not require that donors' identities be disclosed but requires that donors be asked whether they would like their identities disclosed, allows donors who choose nondisclosure to later change their minds, and requires good-faith efforts to disclose donors' nonidentifying medical history to donor-conceived persons upon request. UPA 2017 has been enacted in Washington and Vermont, is pending in Rhode Island, and is anticipated to be introduced in several others states in upcoming legislative terms (20).

In addition to the UPA, in 2008 the American Bar Association (ABA) proposed the Model Act Governing Assisted Reproductive Technology (“ABA Model Act”) after a 15year drafting project that incorporated many organizations. Its purpose was to create "a flexible framework of legal rights, obligations, and protections to the stakeholders in ART," including "patients, participants, parents, providers, and the resulting children and their siblings" (21). Like the UPA, state legislatures must enact ABA Model Act provisions before they have legal force; no state has yet adopted it. It also includes standards for documented informed consent and mandatory disclosures, including recommendations to seek legal counsel. Under the ABA Model Act, a gamete donor is not considered to be a parent of a child conceived through ART; an individual who provides gametes with the intent to parent is a parent and not a donor. Donors can remain anonymous if they provide nonidentifying health information (an increasingly unrealistic provision given the growing popularity of directto-consumer genetic testing). Donors can place nondiscriminatory conditions on their donations; these provisions must be set forth in writing prior to the donation. Donor compensation must be reasonable and not conditioned on gamete quality or genetic traits. The ABA Model Act requires that all third-party reproduction participants must meet in person with a licensed Master- or Ph.D.-level mental health professional.

\section{Enacted State Laws}

Few states have laws applying to oocyte donation; existing state laws regarding parentage are most often modeled after the UPA provisions for sperm donation. According to Swain (4), in 2014 fewer than 15 states had laws addressing egg donation, leaving many participants with no "absolute assurance that the intended mother would be considered a legal parent." But remarkably few oocyte donation conflicts have resulted in case law-a development perhaps attributed to "carefully drawn safeguards, now practiced with regularity," and "a general contentment with the practice of donation" (4). A few states, such as California after high-profile embryo and gamete mix-ups there, have enacted laws requiring specific procedures and disclosures before gamete or embryo donation. Under the California statute, a physician's failure to obtain required written consent or unauthorized use of genetic material carries potential criminal and civil liability (22). New York's reproductive tissue bank regulations go further, allowing reproductive tissue donors the right to withdraw consent to donating stored gametes (requiring a gamete donor's informed consent to include "a statement that the reproductive tissue donor has the right to withdraw his/her consent to donation up until such time that a specific recipient has begun an assisted reproduction cycle in reliance on the availability of tissue from that donor") (23).

The relative paucity of statutory and case law also means that outcomes of existing conflicts are more difficult to predict, whether they concern parentage status, misuse of donor eggs, or improper informed consent.

\section{CASE LAW ADDRESSING OOCYTE DONATION AND RELATED ISSUES}

Case law regarding oocyte donors and oocyte donation reveals four general themes: donors' ability to set conditions in donation negotiations; establishing parenthood and nonparenthood (primarily cases of surrogacy and divorcing same-sex couples); testing donors for (and disclosing information about) genetic conditions; and donor compensation (price-fixing and taxation).

The first issue is theoretically the least controversial: 0ocyte donors can impose nondiscriminatory conditions on recipients' future use of their oocytes or any resulting embryos (a donor cannot express willingness to donate only to a heterosexual couple). If these conditions are included in donation contracts with recruiting programs or with specific recipients, intended parents cannot donate oocytes or resulting embryos to others either at all or without express written permission (24). In Options National Fertility Registry $v$. American Society for Reproductive Medicine (25), an oocyte donor signed an oocyte donor program agreement consenting to donate oocytes only to a couple at a Texas fertility clinic but sued after learning that her oocytes were shared with another couple without her authorization. The fertility clinic and consulting physicians were found liable for failure to comply with the agreement. Such issues will diminish in importance, however, as egg donation programs become more standardized and particularly as frozen egg banks become more widely used.

\section{Establishing Parenthood}

When establishing parenthood in ART contexts, courts have considered two legal issues: whether a woman who contributes an oocyte is a "donor" or an "intended parent"; and whether a woman who does not contribute her own oocyte but intends to be a mother is a mother. These issues usually occur in a few scenarios: third-party reproduction using surrogacy, and divorcing couples where one partner claims the other is not a parent. Both situations raise the question of who is a parent (usually, a mother), based on one or more characteristics such as genetic relationship, gestational pregnancy, legal process (adoption or parentage order), or intent to parent.

Surrogacy. Intent to parent is likely determinative when courts adjudicate who is the parent of children born from surrogacy and oocyte donation. In the seminal custody dispute case Johnson v. Calvert (26), the California Supreme Court confronted the question of whether a gestational (surrogate) 
relationship to a child was superior to a genetic relationship when determining legal parentage. The court ruled that, when the intended mother provides the oocyte, that intention to procreate was a stronger legal indicium of parentage. Thus, the "natural mother" was the woman who was genetically related to the child and intended to parent-not the nongenetic surrogate who gestated the child.

How best to determine parentage after the use of donor oocytes initially mired many trial courts in swamps of contradictory and confusing legal doctrines. Ironically, courts initially relied on the use of donor oocytes to deny women legal parenthood. The trial court in In re Buzzanca (27), for instance, initially ruled that a wife in a divorcing couple could not be the legal mother of a child born through gestational surrogacy because she had neither contributed the oocytes nor given birth to the child-a finding reversed on appeal. Other early cases featured divorcing husbands who used the circumstances of their child's birth via sperm donation to disclaim paternity; courts roundly repudiated such claims (28) and determined that these fathers were liable for child support and that their ex-wives were legal mothers (29).

Legally, a determination that a woman is an "oocyte donor" means that she cannot be a parent. Courts usually find it easier to adjudicate parental rights in gestational surrogacy (where surrogates gestate fetuses conceived either through the intended mother's oocytes or donor oocytes) than in genetic or traditional surrogacy (where surrogates provide both oocytes and gestational services). Usually, oocyte donors for gestational surrogacy sign forms acknowledging their nonparental rights before donation and relinquishing any parental rights that the law might deem them to have. One court stated that such an oocyte donor should be treated like a sperm donor; both anonymously contribute genetic material for payment and sign away all biologic, parental, and legal rights to their gametes and any resulting children (30).

Moreover, courts have determined that use of an anonymous oocyte donor does not preclude a woman who gestates and intends to parent a child from claiming parental status, regardless of whether or not she has a partner or is married. McDonald $v$. McDonald (28) featured a married couple who conceived a child through IVF with the use of anonymousdonor oocytes and the husband's sperm; when the couple separated, the husband claimed a superior right to custody because of his genetic relationship to the child. The court found that, because both parents had expressed parental intentions, the wife was the natural mother and the husband did not have a superior custodial claim. Similarly, in In re C.K.G. (31), an unmarried couple conceived triplets with the use of anonymous-donor oocytes and the male partner's sperm; both partners lived together and fulfilled parental responsibilities. After their relationship deteriorated, the female partner sued for custody and child support, and the father asserted that she was not a parent because she was not genetically related to the children. The court, however, declared her the legal mother and granted her primary custody.

In genetic surrogacy cases (the term which UPA 2017 adopts in lieu of "traditional" surrogacy), although the surrogate could be considered to be both an oocyte donor and a gestational surrogate, courts usually do not regard them as such. Although one court stated that an unmarried female "oocyte donor" who was also the gestational surrogate could be considered to be a parent under the state's ART statute (32), most courts do not consider genetic surrogates to be "oocyte donors" for two reasons: their oocytes might not be fertilized in vitro and are not implanted into another woman's uterus; and, unlike an oocyte donor, they cannot be precluded from claiming biologic or legal parenthood under most states' adoption laws and public policies (33). In such cases, courts may, however, look to the intention of the surrogate and the intended parents, especially whether there are any agreements or behaviors indicating whether or not the surrogate would coparent (31). In addition, in most states, traditional surrogates cannot be asked to relinquish parental rights until after birth, and surrogacy contract provisions requiring such commitments are legally unenforceable.

Divorcing or separating same-sex couples. Determining parentage in cases involving same-sex parents who conceived through ART also has posed many quandaries for courts. When one woman in a committed lesbian relationship provided her oocytes to her partner (usually after signing standard "oocyte donor" clinic consent forms denying or relinquishing parental rights) and her partner gestated the resulting pregnancy, was the genetic connection and expressed intention to parent enough to establish parental rights if the couple separated? Courts confronted this exact situation in the famous case K.M. v. E.G. (33). After E.G. was unable to conceive with the use of her own eggs, her doctor suggested using K.M.'s ova; K.M. signed a generic oocyte donor form that she had seen only 10 minutes beforehand and signed it with the intention to parent, believing that some provisions (including promising not to discover the recipient's identity, and relinquishing parental rights) would not pertain. Using K.M.'s oocytes, E.G. conceived twins, whom both women parented. After the two separated, E.G. contested K.M.'s parental claims. Although the lower court ruled that K.M. was an "oocyte donor" and not a parent, the California Supreme Court reversed, finding that both women intended to conceive a child that would be raised in their home, and that K.M.'s genetic relationship to the children was evidence of a parental relationship under California law (based on the UPA). In addition, it invalidated the oocyte donor waiver, reasoning that parents could not use agreements to limit or eliminate a child's right to support, distinguishing women in K.M.'s situation from sperm and true gamete donors. The Florida Supreme Court reached a similar result in D.M.T. v. T.M.H. (35), declaring unconstitutional a state statute requiring that oocyte providers in same-sex relationships relinquish parental claims, regardless of whether they intend to parent offspring.

Following the U.S. Supreme Court's ruling in Obergefell $v$. Hodges (18) recognizing the right of same-sex couples to marry, many same-sex patients enter into ART arrangements on the assumption that each will be fully recognized as a legal parent. Nonetheless, because of the patchwork of state parentage laws and uncertainties that may remain, to ensure joint legal parentage most ART lawyers counsel their LGBTQ 
clients to obtain either a joint parentage order or an adoption order, depending on the jurisdiction (36).

\section{Alleged Negligence: Embryo Mix-Ups and Donor Genetic Testing}

Other complicated third-party reproduction scenarios concern testing of sperm and oocyte donors for genetic diseases and negligent embryo mix-ups. These cases are much more unusual than parentage and custody determinations, but the lack of legal precedents makes them more challenging.

Regarding donor genetic testing, courts have ruled that clinics have a legal duty both to test oocyte donors for certain common genetic conditions and to communicate those test results to intended parents. In B.F. et al. $v$. Reproductive Medical Associates of New York, LLP (37), New York's highest state court, the New York Court of Appeals, adjudicated the malpractice claims of parents who underwent IVF with the use of anonymous-donor oocytes and learned after the child's birth that their child had fragile X syndrome from the donated oocytes, a genetic disorder causing intellectual disabilities and other conditions. The court found that the clinic's failure to test the oocyte donor for fragile X deviated from the medical standard of care, that this nondisclosure meant that the clinic did not obtain the couples' informed consent to procedures, and that the couple's claim met the criteria for punitive damages. In a second case, Paretta $v$. Medical Offices for Human Reproduction (38), parents alleged that their clinic had not told them that their oocyte donor had tested positive for the cystic fibrosis gene, that they had not tested the husband for the condition, and that their child was born with the condition. A New York court ruled that the couple could obtain the financial costs of the child's care and treatment but noted that a child conceived through ART did not have a right to be born free of genetic defects, just like a child conceived through sexual intercourse, and thus did not have "more rights and expectations" than other children (38).

One additional case involving an embryo mix-up illustrates how women who use oocyte donors can have a weaker (or nonexistent) claim to parental rights because they lack a genetic relationship to the child. In Robert $B$. v. Susan B. (39), a married couple, Robert and Denise, underwent IVF, creating embryos with the use of an oocyte donor and Robert's sperm. Although some of the embryos were transferred to Denise, three were also mistakenly given to Susan, a single woman in the same practice who was supposed to receive an anonymously donated embryo. Both Denise and Susan became pregnant but did not learn of the clinic's error until 10 months after the children's births. Robert and Denise sued after they asked Susan to voluntarily relinquish her parental rights and she refused. The court determined that Robert was the biologic father (not a sperm donor) and could get visitation rights but dismissed Denise from the case because she was not the child's biologic or gestational mother. The court reasoned that the facts in this strange case were very different from the usual thirdparty reproduction scenario, in which an intended mother contracted with a surrogate. Thus, the court ruled, Susan was the legal mother because she had given birth to the child and was the intended mother.

\section{Oocyte Donor Compensation}

In legal disputes concerning oocyte donor compensation, courts have adjudicated two issues: whether donor compensation guidelines of professional medical societies like ASRM and the Society for Assisted Reproductive Technology (SART) were "price-fixing" in violation of antitrust laws; and whether payments to oocyte donors were taxable under federal income tax laws.

In Kamakahi v. American Society for Reproductive Medicine et al. (40), an oocyte donor brought a class action lawsuit on behalf of other donors against ASRM, SART, and a number of fertility clinics, alleging that these organizations had engaged in "price-fixing" by establishing and enforcing oocyte donor payment guidelines. The suit was settled out of court: under the settlement, ASRM and other defendants would remove language in its guidelines stating that payments over $\$ 5,000$ should be justified and payments over $\$ 10,000$ were not appropriate, and "will not set forth any dollar amounts of recommended or requiring levels or ranges of compensation" (34).

In Perez. v. Commissioner of Internal Revenue (41), the U.S. Tax Court ruled that payments to oocyte donors were taxable for federal income tax purposes. An oocyte donor who had received a large payment for donated oocytes did not report the payment on her annual tax return, and thereafter received notice of nonpayment from the Internal Revenue Service. She appealed, arguing that under her oocyte donor contract that payment was for pain and suffering, and should not be taxable. The U.S. Tax Court disagreed, ruling that compensation for pain and suffering resulting from consensual performance of a service contract must be included in gross income.

\section{EMERGING LEGAL ISSUES AND CLINICAL RECOMMENDATIONS}

Novel legal issues and new clinical challenges are likely to arise with the advent of oocyte freezing and proliferation of "egg banks." As an initial question, legally determining what an egg bank is will affect what type of law applies and thus what obligations, responsibilities, and vulnerabilities may arise regarding egg banks and those who use them. It is a cardinal rule of health law that physicians have a "duty to warn" their patients, and through them their family members, about genetically related conditions (42). Some seminal cases suggest that physicians who are told or otherwise know that patients will not inform their family may have an obligation to directly warn family members (43). Translating that health law principle into gamete donation raises challenging questions. Are genetically related offspring now "family"? If an egg bank is an independent corporate entity that receives a donor's retrieved and cryopreserved oocytes from a fertility center for storage and subsequent dissemination, does any "duty to warn" of subsequently 
discovered genetic anomalies extend to it? If not, how are genetically affected individuals protected as the duty to warn anticipates? But if such a duty does extend to egg banks, how would it be applied and how far would it extend? A similar common law duty exists in adoption law, where an agency may be liable for fraud or negligence, often described as "wrongful adoption," if they fail to disclose known heritable conditions of a birth parent to prospective adoptive parents (44). It may simply be too soon to know with any degree of certainty what legal duties will apply to egg banks or other nonmedical programs that facilitate oocyte donation. Despite ASRM guidelines that require "permanent records" of donation to be maintained (6), neither ASRM nor the government has established a uniform donor registry to track either genetically related information or donor health issues.

Another emerging legal issue involves the reality that anonymity in gamete donation, as it was understood in earlier times, no longer exists. In an era of direct-to-consumer genetic tests, donor-conceived offspring, donors, and their relatives are all learning of one another's existence and identities, and all donor programs should ensure that their documents, websites, and other representations are updated to reflect that reality. Outside of the United States, numerous countries prohibit or restrict anonymous donation altogether, or provide a unilateral right for donor-conceived offspring to learn their donors' identities upon reaching a certain age, regardless of any prior agreement as to anonymity $(45,46)$. Moreover, international bodies of law recognize the right to know one's identity as a central right of an individual $(47,48)$.

In general, providers should place renewed emphasis on counseling both oocyte donors and recipients about the importance of and opportunities for mental health consultations and legal advice before donating or receiving donor oocytes. New technologic innovations will undoubtedly change standard-of-care practices. For example, egg freezing will necessitate different legal norms and clinical practices. Donors can provide oocytes that are cryopreserved and then banked, ready for intended parents' selection, adding interpersonal distance between donor and recipient, eliminating any individual contracts or limits, and making donor oocytes more like donor sperm. Egg banks and providers, not intended parents, will initially choose whether a particular oocyte donor is desirable. Banking donor oocytes makes it easier to standardize practices such as genetic testing of donors, potentially providing recipients with greater information. But recipients who can choose oocytes directly from an egg bank without contract negotiations might be less likely to obtain any nonrequired mental health or legal counseling. Similarly, egg banking will mean that both donors and intended parents will sign standardized forms instead of negotiating customized contracts. This, in turn, reduces donors' ability to place conditions on donor oocytes, such as prohibiting intended parents from donating surplus embryos to others. Moreover, given fast-moving genetic testing developments and extended storage and use possibilities, providers will face difficult ethical decisions, such as determining when previously banked oocytes have been adequately screened based on current testing standards. These challenges can often be addressed, if not met, through transparency, enhanced coun- seling for oocyte donors and recipients, and stronger reminders that relevant policies and laws are subject to change.

\section{CONCLUSION}

Although it is still a relatively recent procedure, oocyte donation has changed medical and legal landscapes, enabling women, men, and couples who previously could not conceive to build families and paving the way for other advances, such as egg-freezing technology. Legislatures have struggled to keep up with the rapid pace of technologic innovation, rendering essential more flexible resources such as professional guidelines and judicial opinions. Thus, partnerships between medical and legal professional associations, as well as incorporation of professional medical standards into statutory law and judicial opinions, will continue to improve medical and legal resources, helping to prevent many conflicts and promote more just outcomes in those disputes that arise.

Acknowledgments: The authors thank Judy Daar for her comments on early drafts of this essay.

\section{REFERENCES}

1. Centers for Disease Control. Assisted reproductive technology national summary report. 2015. Available at: https://www.cdc.gov/art/pdf/2015-report/ ART-2015-National-Summary-Report.pdf. Accessed July 13, 2018.

2. Steinbock B. Payment for egg donation and surrogacy. Mt Sinai J Med 2004, 71:255-65.

3. Blakeslee S. Infertile women has baby through embryo transfer. New York Times; 1984. Available at: https://www.nytimes.com/1984/02/04/us/infertile-woman-has-baby-through-embryo-transfer.html. Accessed July 13, 2018.

4. Swain ME. Oocyte donation: legal aspects. In: Goldfarb JM, editor. Thirdparty reproduction: a comprehensive guide. Springer; 2014:2-14.

5. Braverman AM. Mental-health counseling in third-party reproduction in the United States: evaluation, psychoeducation, or ethical gate-keeping? Fertil Steril 2015;104:501-6.

6. Practice Committee of the American Society of Reproductive Medicine; Practice Committee of the Society for Assisted Reproductive Technology. Recommendations for gamete and embryo donation: a committee opinion. Fertil Steril 2013;99:e3-10.

7. Ethics Committee of the American Society of Reproductive Medicine. Interests, obligations, and rights in gamete donation: a committee opinion. Fertil Steril 2014;102:675-81.

8. Ethics Committee of the American Society of Reproductive Medicine. Financial compensation of oocyte donors: a committee opinion. Fertil Steril 2016; 106:e15-19.

9. Practice Committee of the American Society of Reproductive Medicine Practice Committee of the Society for Assisted Reproductive Technology. Repetitive oocyte donation: a committee opinion. Fertil Steril 2014;102: 964-6.

10. Ethics Committee of the American Society of Reproductive Medicine. Using family members as gamete donors or gestational carriers: a committee opinion. Fertil Steril 2015;107:1136-42.

11. Ethics Committee of the American Society of Reproductive Medicine. Oocyte or embryo donation to women of advanced reproductive age: a committee opinion. Fertil Steril 2016;106:e3-7.

12. Ethics Committee of the American Society of Reproductive Medicine. Childreading ability and the provision of fertility services: a committee opinion. Fertil Steril 2017;108:944-7.

13. Ethics Committee of the American Society of Reproductive Medicine. Misconduct in third-party assisted reproduction: a committee opinion. Fertil Steril 2014;101:38-42. 
14. Ethics Committee of the American Society of Reproductive Medicine. Disclosure of medical errors involving gametes and embryos: a committee opinion. Fertil Steril 2016;106:59-63.

15. National Organ Transplant Act, 42 U.S.C. $\S \S 274-274$ e (2018).

16. Crockin SL. Statutory and case law governing oocyte and embryo donation. In: Sauer MV, editor. Principles of oocyte and embryo donation. London: Springer; 1998:241-69.

17. Joslin C, Pederson J. Updated National Uniform Parentage Act (UPA 2017) approved. ASRM News; 2017. Available at: https://www.asrm. org/news-and-publications/news-and-research/legally-speaking/updatednational-uniform-parentage-act-upa-2017-approved/. Accessed July 13, 2018.

18. Obergefell v. Hodges, 135 S.Ct. 2584 (2015).

19. Pavan v. Smith, 137 S. Ct. 2075 (2017).

20. Uniform Law Commission. Enactment status map. Available at: http:// www.uniformlaws.org/Act.aspx?title=Parentage\%20Act\%20. Accessed August 5, 2018.

21. Cal. Pen. Code $\S 367 \mathrm{~g}$ (2007).

22. N.Y. Comp. Codes R. \& Regs, $\S \S 52-8.7,52-58.8$ (2000).

23. Kindregan CP, Snyder SH. Clarifying the law of ART: the new American Bar Association Model act governing assisted reproductive technology. Fam Law Q 2008;42:203-28.

24. Litowitz v. Litowitz, 48 P.3d 261 (Wash. 2002).

25. Options Nat. Fertility Registry v. Am. Soc. For Reprod. Med., No. C 07-5238 JF (HRL), 2009 WL 1393555 (N.D. Cal. May 15, 2009).

26. Johnson v. Calvert, 851 P.2d 776 (Cal. 1993).

27. In re Buzzanca, 61 Cal. App. 4th 1410 (Cal. Ct. App. 1998).

28. McDonald v. McDonald, 196 A.D. $2 d 7$ (NY Sup. Ct. 1994).

29. Ezzone v. Ezzone, Ohio No. 96 DR 000359, Ct. Common Pleas, Dir. Dom. Rels. (Ohio Oct 24, 1997).

30. J.F. v. D.B., 66 Pa. D. \& C.4th 1 (Com. Pl. 2004)

31. In re C.K.G., 173 S.W.3d 714 (Tenn. Oct 6, 2005)
32. L.F. v. Breit, 736 S.E.2d 711 (Va. 2013).

33. A.L.S. ex rel. J.P. v. E.A.G., No. A10-443, 2010 WL 4181449 (Minn. Ct. App. Oct. 26, 2010).

34. K.M. v. E.G., 117 P.3d 673 (Cal. 2005).

35. D.M.T. v. T.M.H., 129 So.3d 320 (FI. 2013).

36. Lambda Legal. Lambda legal applauds New York court ruling affirming adoption rights for married same-sex couples. 2016. Available at: https:// www.lambdalegal.org/blog/20161012_court-ruling-affirming-adoptionrights.

37. B.F. v. Reproductive Medicine Assoc. of N.Y., LLP, 136 A.D.3d 73 (N.Y. App. Div. 2015), aff'd, 92 N.E.3d 766 (2017).

38. Paretta v. Medical Offices for Human Reproduction, 760 N.Y.S.2d 639 (Sup. Ct. 2003).

39. Robert B. v. Susan B., 109 Cal. App. 4th 1109 (Cal. Ct. App. 2003).

40. Kamakahi v. Am. Soc'y for Reprod. Med., No. 3:11-CV-781 JCS, 2016 WL 7740288 (N.D. Cal August 26, 2016).

41. Perez. v. Commissioner of Internal Revenue, 144 T.C. 51 (2015).

42. Pate v. Threlkel, 661 So.2d 278 (Fla. 1995).

43. Safer v. Estate of Pack, 677 A.2d 1188 (N.J. App. Div. 1996).

44. Meeker v. McLaughlin, No. 17-CV-5673 (SN), 2018 Westlaw 3410014 (S.D.N.Y. July 13, 2018).

45. Assisted Reproductive Treatment Act. 2008 (Victoria, Australia). Available at: http://www8.austlii.edu.au/au/legis/vic/consol_act/arta2008360.pdf. Accessed August 7, 2018.

46. Cohen IG. Sperm and egg donor anonymity: legal and ethical issues. In: Francis Leslie, editor. Oxford handbook of reproductive ethics. New York: Oxford University Press; 2015:499-535.

47. Farnós Amorós E. Donor anonymity, or the right to know one's origins? Catalan Soc Sci Rev 2015;5:1-10.

48. Lyons D. Domestic implementation of the donor-conceived child's right to identity in light of the requirements of the UN Convention on the Rights of the Child. Int J Law Policy Fam 2018;32:1-26. 